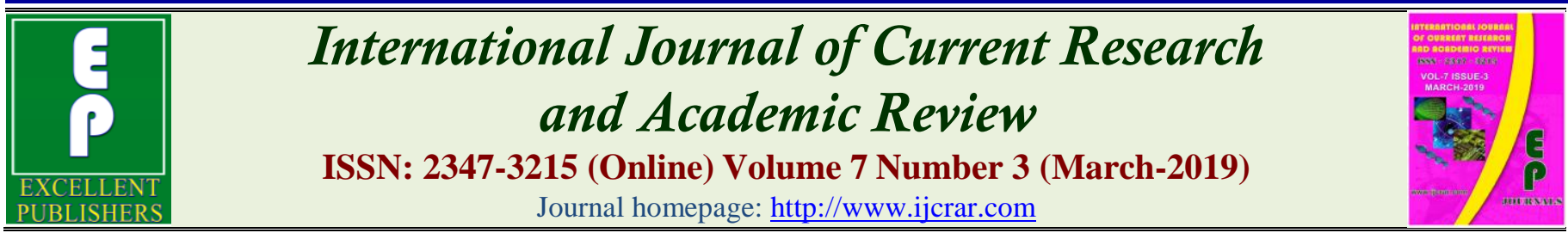

doi: https://doi.org/10.20546/ijcrar.2019.703.003

\title{
Determination of Antibacterial Activity of Cell Free Extracts of Lactobacillus bulgaricus and Streptococcus thermophilus against Local Isolates of E. coli O157:H7
}

\author{
Zainab M. AlZubaidy* \\ Diyala University/College of Science, Iraq \\ *Corresponding author
}

\section{Abstract}

Escherichia coli serotype O157:H7 is a recently recognized human pathogen associated with hemorrhagic colitis, the efficacy of MacConkey agar containing sorbitol (SMAC medium) instead of lactose as a differential medium for the detection of E. coli O157:H7 in foods cultures was determined in comparison with MacConkey agar. The study involving 200 different food samples, the growth of $E$. coli $\mathrm{O} 157: \mathrm{H} 7$ on SMAC medium was appeared and purified in pure culture as colorless colonies in contrast to other E. coli, from the total(200) different ready to eat food samples; 96(66.7\%) were contaminated with bacteria E. coli $\mathrm{O} 157: \mathrm{H} 7$ and $48(33.3 \%)$ for other E. coli. Bacteriological investigation were done on (200) samples of (meat steak, grilled chicken, shawerma meat and chicken), the result indicated that $144(72 . \%)$ of samples was contaminated with $E$. coli divided as $96(66.7 \%)$ and $48(33.3 \%)$ for E. coli $\mathrm{O} 157: \mathrm{H} 7$ and other $E$. coli respectively. The percentage of contamination with $E$. coli $\mathrm{O} 157: \mathrm{H} 7$ isolated from meat steak, meat shawerma, chicken shawerma, grilled chicken samples were $16(16.6 \%), 27(28.1 \%)$, $32(33.33 \%), 21(21.8 \%))$ respectively. The susceptibility of $E$. coli to different antimicrobial drugs was carried out using antibiotic discs, the percentage of sensitivity were $(100,93.7,89.5$, 58.3, 50)\%. Against danofloxacin, imipenem, fosfomycin, ciprofloxacin, azithromycin, respectively, and $41.6 \%$ for each; trimethoprim, gentamicin and doxycyclin. On the other hand the resistance to ampicillin, amikacin, amoxicillin, cefixime and tertracycline were $(97.9,95.8$, $89.5,68.7,56.2) \%$ while the isolated bacteria appeared the resistance percentage $(83.3 \%)$ to chloramphenicol and erythromycin, while it was varied in resistant to cephalothin, nalidixic acid and cefazoline. All the isolates of E. coli O157: H7 96(100\%) were resistance to ampicillin, amikacin, chloramphenicol and erythromycin, as well as were resistance to tetracycline, amoxicillin, cefixim and trimethoprim, while all the isolates $96(100 \%)$ were sensitive to danofloxacin. The percentage of resistance to gentamycin and nalidixic acid were 38(39.5), and the resistant to azithromycin, cefazoline, doxycycline and cephalothine were varied as $80(83.3)$, 46(47.9), 44(45.8) and 40(41.6), respectively. In present study Cell free extract (CFE) metabolites of lactic acid bacteria (LAB) include (2) strains of Lactobacillus bulgaricus (LB), and Streptococcus thermophilus (ST) grown in MRS and M17 media have inhibitory effect against E. coli O157:H7and E. coli, by using well diffusion method. The minimum inhibitory concentration of CFE of Lactobacillus bulgaricus and Streptococcus thermophilus at 50, 75 and $100 \mu \mathrm{v} / \mathrm{v}$ which concentrated for two folds, appeared that the inhibition zones increase as the concentration of CFE increase, and ranged from (10-16) $\mathrm{mm}$ against bacteria $E$. coli, while the effect of Streptococcus thermophilus varied between (6-10) $\mathrm{mm}$ against same bacteria. On the other hand the effect of Lb. bulgaricus and St. thermophiles on the growth of E. coli O157:H7 were ranged between (12-20) $\mathrm{mm}$ and (5-14) $\mathrm{mm}$ respectively, The recent study demonstrated that the two genus of starter bacteria when cultured together gave the greatest antibacterial activity against the two isolates $E$. coli and E. coli O157:H7, and the inhibition zone was increased as $12-22 \mathrm{~mm}$. and $12-18 \mathrm{~mm}$, respectively.
\end{abstract}

\section{Article Info}

Accepted: 04 February 2019

Available Online: 20 March 2019

\section{Keywords}

E. coli 0157:H7,

Starter, SMAC media. 


\section{Introduction}

Escherichia coli associated with the common flora of the human and animal gastrointestinal tract, several pathogenic types of $E$. coli can lead to diseases. Escherichia coli have been identified as a pointer microorganism for food safety (Adams and Moss, 2000). Although most of the members of this species are harmless to the intestinal lumen, some acquired virulence factors and can cause a wide range of human diseases (Nataro et al., 1998). The pathogenic E. coli is causative of three clinical syndromes: urinary tract infections, enteric/diarrheal diseases and meningitis (Kaper et al., 2004). The key mechanisms by which E. coli cause enteric diseases include attachment and colonization of the intestinal mucosa, manipulation of the host cell cytoskeleton or evading host immune defenses, and production of toxins (Torres, 2009). Six categories of pathogenic E. coli are well-studied and comprise enteropathogenic $E$. coli, enterotoxigenic $E$. coli, enteroaggregative $E$. coli, enterohaemorrhagic $E$. coli, diffusely adherent $E$. coli and enteroinvasive $E$. coli (Croxen and Brett Finlay, 2012). E. coli O157: H7 is a serotype most frequently isolated from patients and shares a variety of virulence factors, including two Shiga toxins, Stx 1 and Stx 2 and a pathogenicity island, termed as the locus for enterocyte effacement, that encodes the proteins responsible for the intimate adherence of $E$. coli to epithelial cells. The production of Shiga toxins by $E$. coliO157: $\mathrm{H} 7$ has a major role in pathogenesis, particularly in the pathogenesis of HUS (Sakagami et al., 2001). Human infection with E. coliO157:H7 has been associated with a variety of contaminated foods, water, and person-to-person transmission (Ammon et al., 1999; Bender et al., 1997). Outbreaks of E. coliO157:H7 infection has been attributed to the presence of this bacterium in groundwater and surface water (Chalmers $e t$ al., 2000; Lee et al., 2002).

Current involvements to treating pathogenic E. coli involve the use of antibiotics. However, many pathogenic strains which have the ability to cause illness became resistant to antibiotics (Collignon, 2009; Tadesse et al., 2012). The increase of antibiotic resistance has interested research to find out antimicrobial substitutes of which probiotics have gained a growing interest. The use of Lactic acid bacteria species as probiotics to fight microbial infections and increasing human health stimulated many studies. Probiotics have been associated with the treatment of gastroenteritis (Chai et al., 2013), antibiotic-associated diarrhoea (Friedman, 2012), necrotizing enterocolitis (Alfaleh et al., 2011), pouchitis
(Wall et al., 2011), inflammatory bowel diseases (Tejero-Sariñena et al., 2012). Moreover, probiotics were capable of reduction of E. coli O157: $\mathrm{H} 7$ and E. coli O127: $\mathrm{H} 6$ adhesion to epithelial cells monolayers (Erdem et al., 2007). The ability of pathogenic E. coli to form biofilms that contribute to their pathogenicity was recognized (Martinez-Medina et al., 2009). The antibiofilm activities of probiotics against pathogenic local isolates E. coli are poorly studied. Here, we aimed to use probiotics to combat multidrug-resistant E. coli and reduce their ability to form biofilms.

\section{Materials and Methods}

\section{Sample collection}

Total of 200 samples of different ready to eat food sources of meat steak, chickens shawrma, meat shawrma, grilled chickens, from restaurants and markets in Erbil city were collected, 50 samples from each sources were obtained. All the samples were collected aseptically, placed in sterile containers, kept at $4^{\circ} \mathrm{C}$, and then transferred to the laboratory. A $25 \mathrm{~g}$ portion from each sample was homogenized in a stomacher with $225 \mathrm{ml}$ of peptone broth medium (Difco Laboratories), then incubated statically at $37^{\circ} \mathrm{C}$ for $4 \mathrm{~h}$. The culture was diluted in tryptone water ( $1 \%$ trypton, $0.5 \% \mathrm{NaCl})$, inoculated onto MacConkey agar (Oxoid, Ltd., England), and incubated overnight at $37^{\circ} \mathrm{C}$, for isolation of $E$. coli O157 was performed according to the Dentorou method with modification (Dontorou et al., 2003). Colonies was streaked on Sorbitol MacConkey agar (SMAC) (Oxoid) which contains cefixime $(50 \mu \mathrm{g} /$ liter $)$ and potassium tellurite 2.5mg/liter (Akiba et al., 2000; Friedman et al., 1999), and incubated at $42^{\circ} \mathrm{C}$ for 24 hours. The API-20E test kit for the identification of enteric bacteria (bioMerieux, Inc., Hazelwood, MO) provides an easy way to inoculate and read tests relevant to members of the Family Enterobacteriaceae and associated organisms. A plastic strip holding twenty mini-test tubes is inoculated with a saline suspension of a pure culture (as per manufacturer's directions). This process also rehydrates the desiccated medium in each tube. A few tubes are completely filled (CIT, VP and GEL), and some tubes are overlaid with mineral oil such that anaerobic reactions can be carried out (ADH, LDC, ODC, $\mathrm{H}_{2} \mathrm{~S}$, URE). After incubation for 18-24 hours at $37^{\circ} \mathrm{C}$, the color reactions are read (some with the aid of added reagents), and the reactions (plus the oxidase reaction done separately) are converted to a seven-digit code which is called the Analytical Profile Index, from which name the initials "API" are derived. 
Motility test of isolates was performed according to Cheesbrough (1985). Briefly, semi-solid agar was prepared using nutrient broth $1.5 \%$ and agar- $0.4 \%$ inoculated with isolated E. coli and S. aureus were taken as positive and negative control, respectively. Antibodies to the O157 antigen were used in this study to detect O157:H7isolates. Cross-reaction of somatic antigen O157and flagella antigen $\mathrm{H} 7$ is established. Isolates from which sorbitol-colorless colonies have been isolated that agglutinates in $\mathrm{O} 157$ antiserum, and are biochemically be reported as presumptively positive for E. coli O157:H7.

\section{Determination of antibiotic sensitivity of $E$. coli isolates}

\section{Susceptibility testing by disc agar diffusion}

Antimicrobial susceptibility was determined by the Kirby- Bauer disk diffusion method according to the method of (Chakraborty et al., 2011). The tested bacterium was from an overnight culture (inoculated from a single colony) and freshly grown for 4 hours at approximately $10^{6} \mathrm{CFU} / \mathrm{ml}$. With this culture, a bacterial lawn was prepared on Mueller-Hinton agar. The standard single-disk method with each of the following antibiotic disks: Amikacin $(10 \mu \mathrm{g} / \mathrm{ml})$, Ampicilln $(10 \mu \mathrm{g} / \mathrm{ml})$, Carbenicillin $(100 \mu \mathrm{g} / \mathrm{ml})$, cefuroxime $(30 \mu \mathrm{g} / \mathrm{ml})$, tetracycline $(30 \mu \mathrm{g} / \mathrm{ml})$, cephalotin $(30 \mu \mathrm{g} / \mathrm{ml})$, nalidixic acid $(30 \mu \mathrm{g} / \mathrm{ml})$, amoxicillin $(30 \mu \mathrm{g} / \mathrm{ml})$, gentamycin $(10$ $\mu \mathrm{g} / \mathrm{ml}$,) chloramphenicol (30 $\mu \mathrm{g} / \mathrm{ml}$; Oxoid), streptomycin $(10 \mu \mathrm{g} / \mathrm{ml}$; Oxoid), rifampin $(15 \mu \mathrm{g} / \mathrm{m})$, norfloxacin $(10 \mu \mathrm{g} / \mathrm{ml})$ danofloxacin, cefazolin, ciprofloxacin, azithromycin, Doxycycline and Erythromycin were used, the diameter of zone of bacterial growth inhibition surrounding the disc (including the disc) was measured and compared with the standard for each drug specified in the interpretative tables, and the results were interpreted as either susceptible, intermediate, or resistant. The tests were done three times, and identical results were obtained for each isolates and for all antibiotics (NCCLS, 2006).

\section{Determination of antibacterial activity of Lactobacillus bulgaricus and Streptococcus thermophilus against isolated bacteria}

\section{Isolation and activation of Lactic Acid Bacteria (LAB)}

Five grams of lyophilized standard Lactobacillus bulbaricus and Streptococcus thermophilus (micro Milk
S.r.I) from Sulaimanyai University/ Faculty of Agriculture, Animal Resource Department, was taken aseptically and transferred to sterile plastic bags and homogenized in $45 \mathrm{ml}$. of sterile $0.1 \%$ (w/v) peptone water as diluents and 7-fold serially diluted. The isolation was performed by the routine microbiological procedure and inoculation on a solid medium using De Man Rogosa Sharp (MRS) agar plates as a selective media for Lactobacillus bulgaricus isolation, and M17 used for Streptococcus thermophilus.

Cell free extract of LAB was prepared according to Hameed (2004), Lactic acid bacteria was inoculated in MRS broth as $2 \%$ of broth volume and incubated in anaerobic condition at $37^{\circ} \mathrm{C}$ for $73 \mathrm{~h}$. The culture then centrifuged at $5000 \mathrm{rpm}$ for $30 \mathrm{~min}$. The Supernatants were sterilized by filtration through $0.22 \mathrm{~mm}$ membranes (Millipore).

The antimicrobial activity for each strains of Lactobacillus bulgaricus and Streptococcus thermophilus, also the two strains together (cell free filtrate) against (Escherichia coli, E. coli O157:H7) which isolated from local food sources was performed by the well diffusion assay. The tested bacteria were incubated in Nutrient broth at $37^{\circ} \mathrm{C}$ for $24 \mathrm{hrs}$. Petri dishes containing $20 \mathrm{ml}$ of Muller Hinton agar were prepared previously and inoculated with $0.1 \mathrm{ml}$ of broth culture of isolated bacteria. Once solidified the dishes were stored for $2 \mathrm{hrs}$ in a refrigerator, then four wells were made and filled with different concentration $(25 \mu$, $50 \mu \mathrm{l}, 75 \mu \mathrm{l}, 100 \mu \mathrm{l})$ of cell-free filtrate, after that the cultured petri dishes were incubated at $37^{\circ} \mathrm{C}$ for $24 \mathrm{hrs}$. Then the diameter of the inhibition zone was measured with calipers in $\mathrm{mm}$. The antimicrobial activity was determined by measuring the clear zone around the wells (Hemashenpagam et al., 2011; Suskovic et al., 1997).

\section{Results and Discussions}

Escherichia coli serotype $\mathrm{O} 157: \mathrm{H} 7$ is a recently recognized human pathogen associated with hemorrhagic colitis. Unlike most E. coli strains, E. coli $\mathrm{O} 157: \mathrm{H} 7$ does not ferment sorbitol. Therefore, the efficacy of MacConkey agar containing sorbitol (SMAC medium) instead of lactose as a differential medium for the detection of E. coli $\mathrm{O} 157: \mathrm{H} 7$ in foods cultures was determined in comparison with MacConkey agar. Non Sorbitol Fermented (NSF) organisms also occurred mostly in high numbers. The study involving 200 different food samples, the growth of $E$. coli $\mathrm{O} 157: \mathrm{H} 7$ on SMAC medium was appeared and purified in pure 
culture as colorless NSF colonies in contrast to other $E$. coli, which are mostly sorbitol fermenting and hence appear pink on this medium, whereas on MacConkey agar cultures, the growth of E. coli O157:H7 was indistinguishable from others as show in the (Fig. 1). Most E. coli O157:H7 lack the capacity to ferment sorbitol; this feature has also been useful to microbiologists because it distinguishes this pathogen from the majority of other E. coli strains (Griffin, 1995; Strockbine et al., 1998).

Some O157 strains express functional flagella (Hantigen); these bacteria are designated $\mathrm{O} 157: \mathrm{H}^{+}$or motile or O157: $\mathrm{H}^{-} \mathrm{NM}$ (non motile). SMAC medium permitted ready recognition of E. coliO157:H7 in food samples which is simple, inexpensive, rapid, and reliable means of detecting E. coli O157:H7. The adopted isolates were identified using standard biochemical tests (Table 1), and were confirmed by API E20 to be Escherichia coli.

The IMViC (Indole, Methyl red, Voges-Proskauer, and Citrate) tests are frequently employed for identification of this group of microbes which includes such organisms as Klebsiella, Enterobacter, and Escherichia coli (Barnes et al., 2003). Our study shows gram negative isolates also indole positive this is due to production of the tryptophanase enzyme by those isolates that can break down the amino acid tryptophan to indole. Indole positivity of those isolates differentiates them from most Klebsiella $s p$ and Enterobacter sp (MacFaddin, 2000). Table 2 shows $100 \%$ of indole positive isolates were MR test positive and VP test negative. MR-VP media contains glucose and peptone Our food isolates can ferments the glucose in MR-VP media that decreases $\mathrm{pH}$ of the media below 4.4, detected by methyl red indicator which turns the media color cherry red. This finding is highly correlated with the finding of (Kanungo, 2009. Urease test was done for the detection of urea hydrolysis ability of those clinical isolates. Negative results were observed for all indole positive isolates. In our study all the isolates were urease negative; this may be due to lack of urease enzyme required for hydrolysis of urea to ammonia (MacFaddin, 2000). Reactions in TSI agar slant revealed that all isolates showed yellow slant with gas production but no production of hydrogen sulphide gas. This indicates the glucose, lactose and sucrose fermentation ability of those isolates. Our results also demonstrated that, all the isolates were motile and had haemolytic activity ( $\alpha$-haemolysis- $74 \%$ and $\gamma$ haemolysis-36\%). Hemolytic activity of isolates reveled that those isolates were pathogenic due to production of haemolysin, which binds with the haemolysin receptor present on the surface of RBC, that favor haemolysis (Zinnah et al., 2007). Isolates were motile due to presence of flagellum, supports for colonization (Ghadir et al., 2010). Satisfactory result on all biochemical tests and colony characteristic on differential agar it was confirmed that all 144 isolate were E. coli. Divided 96 isolates was $E$. coli $O 157: H 7$ which had colorless colony when cultured on MacConkey sorbitol agar

\section{Distribution of $E$. coli and $E$. coliO157:H7 in local food samples}

Bacteriological investigation were done on (200) samples of (meat steak, grilled chicken, shawerma meat and chicken), the result indicated that 144 (72.\%) of samples was contaminated with E. coli divided as 96 $(66.7 \%)$ and $48(33.3 \%)$ for $E$. coliO157:H7and other $E$. coli respectively as appeared in Figure 2. The percentage of contamination with $E$. coli $\mathrm{O} 157: \mathrm{H} 7$ isolated from meat steak, meat shawerma, chicken shawerma, grilled chicken samples were 16(16.6\%), 27(28.1\%), $32(33.33 \%), 21(21.8 \%)$ respectively Figure 3.

\section{Antibiotics sensitivity of $E$. coli}

The susceptibility of isolated bacteria to different antimicrobial drugs was carried out using antibiotic discs. The result showed that isolated E. coli were high sensitive to danofloxacin, imipenem, fosfomycin, ciprofloxacin, azithromycin, when percentage of sensitivity were $(100,93.7,89.5,58.3,50) \%$ respectively, and $41.6 \%$ for each; trimethoprim, gentamicin and doxycyclin. On the other hand the resistance to ampicillin, amikacin, amoxicillin, cefixime and trtracycline were $(97.9,95.8,89.5,68.7,56.2) \%$ while the isolated bacteria appeared the resistance percentage (83.3\%) to chloramphenicol and erythromycin, while it was varied in resistant to cephalothin, nalidixic acid and cefazoline as shown in table 2 and Figure 3.

Antibiotic resistance is a major clinical problem in treating infections caused by E. coli. The resistance to the antimicrobials has increased over the years and normal intestinal microbial flora became a reservoir for resistant genes (Okeke et al., 2000). This may be due to an inevitable genetic response to the strong selective pressure imposed by antimicrobial chemotherapy, which plays a vital role in the evolution of antibiotic resistance among bacteria. These bacteria then pass the plasmid containing resistant gene among other bacterial cells and species (Chakraborty et al., 2011a). The sensitivity of 
isolated bacteria $E$. coli $\mathrm{O} 157: \mathrm{H} 7$ to classical antibiotics was carried out using antibiotic discs (oxide). The result showed that all the isolates were resistance $96(100 \%)$ to ampicillin, amikacin, chloramphenicol and erythromycin, as well as were resistance to tetracycline, amoxicillin, cefixim and trimethoprim, while all the isolates $96(100 \%)$ were sensitive to danofloxacin. The percentage of resistance to gentamycin and nalidixic acid were 38(39.5), thus the resistant to azithromycin, cefazoline, doxycycline and cephalothine were varied as 80(83.3), 46(47.9), 44(45.8) and 40(41.6) respectively as shown in table 3 .

\section{Antibacterial Activity of Lactobacillus bulgaricus and Streptococcus thermophiles against $\mathrm{E}$. coli O157:H7}

Cell free extract (CFE) metabolites of lactic acid bacteria (LAB) include (2) strains of Lactobacillus bulgaricus (LB), and Streptococcus thermophilus (ST) grown in MRS media have inhibitory effect against isolated E. coli O157:H7 and E. coli. By using well diffusion method, the inhibitory effect of Lactobacillus bulgaricus (LB) cell free extract were variable The minimum inhibitory concentration of CFE of LAB against E. coli and E. coli O157:H7 at (50,75 and 100) $\mu \mathrm{l} \mathrm{v} / \mathrm{v}$ of CFE which concentrated for two folds, the inhibition zones increase as the concentration of CFE increase and ranged from (10-16)mm against bacteria $E$. coli, while the effect of Streptococcus thermophilus (ST) varied between (6-10) $\mathrm{mm}$ against same bacteria. On the other hand the effect of LB and ST on the growth of E. coli O157:H7 were ranged between $(12-20) \mathrm{mm}$ and $(5-14) \mathrm{mm}$ respectively as shown in table 4, the inhibition zone was increased when the concentration of cell free extracts increased as shown in figure $3 \mathrm{~A}, \mathrm{~B}$ and $\mathrm{C}$.

LAB produces many antimicrobial substances like organic acids, hydrogen peroxide and bacteriocins were inhibit other bacteria and fungi (Zarringhalam et al., 2006).

The products of LAB metabolites contribute preservation, flavor, aroma and texture, thereby helping to determine unique product characteristics (Pereira et al., 2008). LAB are used as natural or selected starters in food fermentations, especially for the manufacture of dairy products with functional and probiotic properties (Hassan Pyar et al., 2011). Different reports show that most lactic acid bacteria (LAB) produce substances that inhibit pathogenic, non-pathogenic and spoilage organisms in fermenting foods and beverages (Schillinger and Lucke, 1989). Lactic acid bacteria have been used successfully, with few adverse effects, to prevent antibiotic associated diarrhea, to treat acute infantile diarrhea and recurrent Clostridium difficile disease and to treat various diarrheal illnesses (Saavedra, and Yolken, 1994; Biller et al., 1995). The antagonistic property is attributed to the lowered $\mathrm{pH}$, the undissociated acids and production of other primary and secondary antimicrobial metabolites produced by LAB.

Table.1 Biochemical tests for isolated bacteria (E. coli O157:H7)

\begin{tabular}{|c|c|}
\hline Biochemical Tests & \% of positive reaction \\
\hline Indole & $\mathbf{1 0 0}$ \\
\hline Catalase & $\mathbf{1 0 0}$ \\
\hline TSI & 100 \\
\hline Hemolysis & $\mathbf{7 4 ~} \boldsymbol{\beta}$ and $\mathbf{3 6} \boldsymbol{\gamma}$ \\
\hline Motility & 100 \\
\hline $\begin{array}{c}\text { Carbohydrate } \\
\text { fermentation Glucose, } \\
\text { Lactose, Sucrose }\end{array}$ & $\mathbf{1 0 0}$ \\
\hline Nitrate reduction & $\mathbf{1 0 0}$ \\
\hline
\end{tabular}


Table.2 Sensitivity of isolated E. coli to antibiotics

\begin{tabular}{|l|c|c|c|c|c|}
\hline Antibiotic & Symbol & $\begin{array}{c}\text { Dose } \\
\mu \mathrm{g} / \mathrm{disc}\end{array}$ & $\begin{array}{c}\text { Resistant } \\
\text { N\% }\end{array}$ & $\begin{array}{c}\text { Intermediate } \\
\text { N\% }\end{array}$ & Sensitive N\% \\
\hline Amikacin & $\mathrm{AK}$ & $10 \mu \mathrm{g}$ & $46(95.8)$ & $2(4.1)$ & ---- \\
\hline Ampicillin & $\mathrm{AM}$ & $10 \mu \mathrm{g}$ & $47(97.9)$ & $1(2.1)$ & ---- \\
\hline Amoxicillin & $\mathrm{AMX}$ & $10 \mu \mathrm{g}$ & $43(89.5)$ & $4(8.3)$ & $1(2)$ \\
\hline Azithromycin & $\mathrm{AZM}$ & $15 \mu \mathrm{g}$ & $16(33.3)$ & $8(16.6)$ & $24(50)$ \\
\hline Cefazoline & $\mathrm{CZ}$ & $30 \mu \mathrm{g}$ & $23(47.9)$ & $16(33.3)$ & $9(18.7)$ \\
\hline Cefixime & $\mathrm{CFM}$ & $5 \mu \mathrm{g}$ & $33(68.7)$ & $5(10.4)$ & $10(20.8)$ \\
\hline Cephalothine & $\mathrm{KF}$ & $30 \mu \mathrm{g}$ & $20(41.6)$ & $16(33.3)$ & $12(25)$ \\
\hline Ciprofloxacin & $\mathrm{CP}$ & $5 \mu \mathrm{g}$ & $8(16.6)$ & $12(25)$ & $28(58.3)$ \\
\hline Chloramphenicol & $\mathrm{CL}$ & $30 \mu \mathrm{g}$ & $40(83.3)$ & $6(12.5)$ & $2(4.16)$ \\
\hline Danofloxacin & $\mathrm{DFX}$ & $5 \mu \mathrm{g}$ & -------- & -------- & $48(100)$ \\
\hline Doxycycline & $\mathrm{DX}$ & $30 \mu \mathrm{g}$ & $22(45.8)$ & $6(12.5)$ & $20(41.6)$ \\
\hline Erythromycin & $\mathrm{E}$ & $15 \mu \mathrm{g}$ & $40(83.3)$ & $6(12.5)$ & $2(4.16)$ \\
\hline Fosfomycin & FO & $200 \mu \mathrm{g}$ & $2(4.2)$ & $3(16.2)$ & $43(89.5)$ \\
\hline Gentamicin & GM & $10 \mu \mathrm{g}$ & $19(39.5)$ & $9(18.7)$ & $20(41.6)$ \\
\hline Imipenem & $\mathrm{IMP}$ & $10 \mu \mathrm{g}$ & $2(4.16)$ & $1(2.1)$ & $45(93.7)$ \\
\hline Nalidixic acid & $\mathrm{NA}$ & $30 \mu \mathrm{g}$ & $19(39.5)$ & $13(27.1)$ & $16(33.3)$ \\
\hline Tetracycline & $\mathrm{TE}$ & $30 \mu \mathrm{g}$ & $27(56.2)$ & $17(35.4)$ & $4(8.3)$ \\
\hline Trimethoprim & TMP & $5 \mu \mathrm{g}$ & $20(41.6)$ & $6(12.5)$ & $20(41.6)$ \\
\hline
\end{tabular}

Table.3 Sensitivity of isolated E. coli $\mathrm{O} 157: \mathrm{H} 7$ to antibiotics

\begin{tabular}{|l|l|l|l|l|l|}
\hline Antibiotic & Symbol & $\begin{array}{l}\text { concentration } \\
\mu \mathrm{g} / \mathrm{disc}\end{array}$ & $\begin{array}{l}\text { Resistant } \\
\text { No.\% }\end{array}$ & $\begin{array}{l}\text { Intermediate } \\
\text { No.\% }\end{array}$ & $\begin{array}{l}\text { sensitive } \\
\text { No;\% }\end{array}$ \\
\hline Amikacin & AK & $10 \mu \mathrm{g}$ & $96(100)$ & ----- & ---- \\
\hline Ampicillin & AM & $10 \mu \mathrm{g}$ & $96(100)$ & ----- & ---- \\
\hline Amoxicillin & AMX & $10 \mu \mathrm{g}$ & $96(100)$ & ----- & ---- \\
\hline Azithromycin & AZM & $15 \mu \mathrm{g}$ & $80(83.3)$ & $10(10.4)$ & $6(6.25)$ \\
\hline Cefazoline & CZ & $30 \mu \mathrm{g}$ & $46(47.9)$ & $32(33.3)$ & $18(18.7)$ \\
\hline Cefixime & CFM & $5 \mu \mathrm{g}$ & $96(100)$ & ---- & ---- \\
\hline Cephalothine & KF & $30 \mu \mathrm{g}$ & $40(41.6)$ & $32(33.3)$ & $24(25)$ \\
\hline Ciprofloxacin & CP & $5 \mu \mathrm{g}$ & $18(16.6)$ & $24(25)$ & $56(58.3)$ \\
\hline Chloramphenicol & CL & $30 \mu \mathrm{g}$ & $96(100)$ & ------ & ------ \\
\hline Danofloxacin & DFX & $5 \mu \mathrm{g}$ & ------- & -------- & $96(100)$ \\
\hline Doxycycline & DX & $30 \mu \mathrm{g}$ & $44(45.8)$ & $12(12.5)$ & $40(41.6)$ \\
\hline Erythromycin & E & $15 \mu \mathrm{g}$ & $96(100)$ & ----- & ----- \\
\hline Fosfomycin & FO & $200 \mu \mathrm{g}$ & $4(4.2)$ & $6(16.2)$ & $86(89.5)$ \\
\hline Gentamicin & GM & $10 \mu \mathrm{g}$ & $38(39.5)$ & $18(18.7)$ & $40(41.6)$ \\
\hline Imipenem & IMP & $10 \mu \mathrm{g}$ & $4(4.16)$ & $2(2.1)$ & $90(93.7)$ \\
\hline Nalidixic acid & NA & $30 \mu \mathrm{g}$ & $38(39.5)$ & $26(27.1)$ & $32(33.3)$ \\
\hline Tetracycline & TE & $30 \mu \mathrm{g}$ & $96(100)$ & ---- & ----- \\
\hline Trimethoprim & TMP & $5 \mu \mathrm{g}$ & $96(100)$ & ---- & ----- \\
\hline
\end{tabular}


Table.4 Antibacterial activity of Lactobacillus bulgaricus and Streptococcus thermophiles against E. coli O157:H7 and E. coli (Zone of inhibition in $\mathrm{mm}$ )

\begin{tabular}{|c|c|c|c|c|}
\hline $\begin{array}{c}\text { Isolated } \\
\text { bacteria }\end{array}$ & $\begin{array}{c}\text { Concentration } \\
\text { of CFE }\end{array}$ & $\begin{array}{c}\text { Lactobacillus } \\
\text { bulgaricus }\end{array}$ & $\begin{array}{c}\text { Streptococcus } \\
\text { thermophilus }\end{array}$ & $\begin{array}{c}\text { L. bulgaricus and } \\
\text { Str. thermophilus }\end{array}$ \\
\hline \multirow{4}{*}{ E.coli } & $25 \mu \mathrm{l}$, & $10 \mathrm{~mm}$ & $6 \mathrm{~mm}$ & $12 \mathrm{~mm}$ \\
\cline { 2 - 5 } & $50 \mu \mathrm{l}$ & $12 \mathrm{~mm}$ & $7 \mathrm{~mm}$ & $15 \mathrm{~mm}$ \\
\cline { 2 - 5 } & $75 \mu \mathrm{l}$ & $13 \mathrm{~mm}$ & $9 \mathrm{~mm}$ & $20 \mathrm{~mm}$ \\
\cline { 2 - 5 } & $100 \mu \mathrm{l}$ & $16 \mathrm{~mm}$ & $10 \mathrm{~mm}$ & $22 \mathrm{~mm}$ \\
\hline \multirow{5}{*}{ E.coliO157:H7 } & $25 \mu \mathrm{l}$, & $10 \mathrm{~mm}$ & $5 \mathrm{~mm}$ & $12 \mathrm{~mm}$ \\
\cline { 2 - 5 } & $50 \mu \mathrm{l}$ & $13 \mathrm{~mm}$ & $7 \mathrm{~mm}$ & $14 \mathrm{~mm}$ \\
\cline { 2 - 5 } & $75 \mu \mathrm{l}$ & $17 \mathrm{~mm}$ & $10 \mathrm{~mm}$ & $18 \mathrm{~mm}$ \\
\cline { 2 - 5 } & $100 \mu \mathrm{l}$ & $17 \mathrm{~mm}$ & $12 \mathrm{~mm}$ & $18 \mathrm{~mm}$ \\
\hline
\end{tabular}

Figure.1 Prevalence of E. coli and E. coli O157:H7. Figure.2 The prevalence percentage of E.coliO157:H7
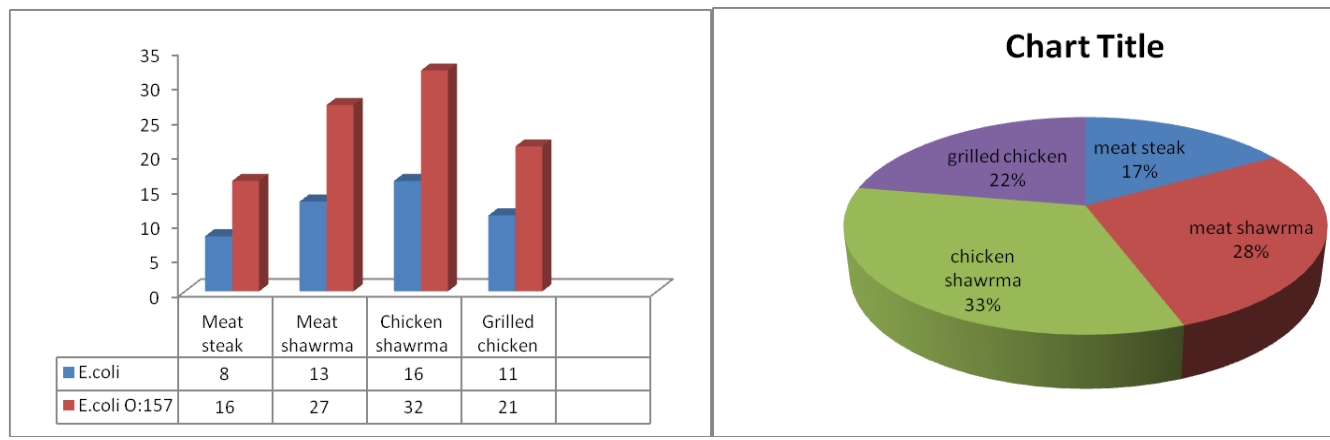

Figure.3 A: Sensitivity of isolated bacteria to antibiotics B and C: The antibacterial activity of different concentration of L. bulgaricus and S. thermophillus cell free extract against E. coli O157:H7 (inhibition zones in mm)

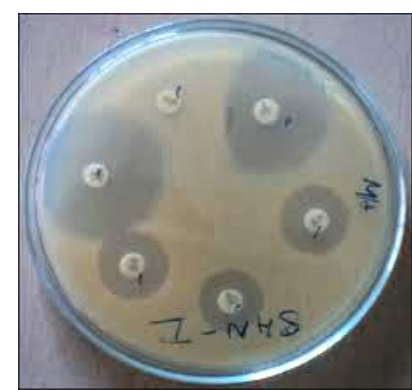

A

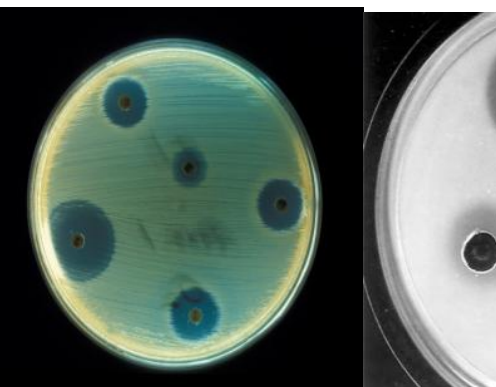

B

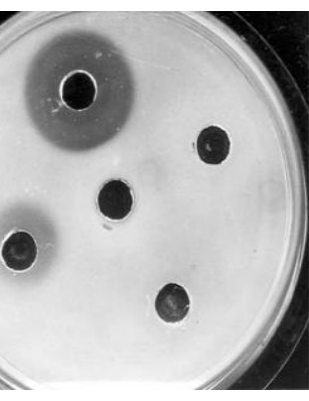

C 
It is evident from the results of the measurement of the diameters of zone of inhibition that the metabolites are significantly effective. This can be explained from the fact that the metabolites produced by the probiotics include bioactive products such as organic acid, hydrogen peroxide $\left(\mathrm{H}_{2} \mathrm{O}_{2}\right)$ and bacteriocins. It was reported that the cell-free supernatant solution from strains of lactic acid bacteria exhibited antimicrobial activity which prevented the growth of different strains of S. aureus and E. coli (Lavermicocca et al., 2000).

In conclusion, the growth of E. coli O157:H7 on SMAC media was occurred in pure culture as colorless non fermented sorbitole colonies in contrast to other E. coli, which are appear pink on this media, whereas on SMAC medium permitted ready recognition of E. coli O157:H7 in food cultures. SMAC media foods culture is a simple, inexpensive, rapid, and reliable means for detecting $E$. coli O157:H7and we recommend routine use of SMAC medium for culturing food samples. The recent study demonstrated that the two genera of starter bacteria when cultured together in MRS broth un aerobically at $37 \mathrm{C}^{\circ}$ for 36hr. gave the greatest antibacterial activity against the two isolates E. coli and E. coli O157:H7. The findings of the study proved that E. coli O157:H7 and other E. coli were isolated from food and all of them were sensitive to the metabolite of lactic acid bacteria strains, however further in vivo studies are needed to performed that.

\section{References}

Ackers M L, Mahon BE, Leahy E, Goode B, Damrow T, Hayes PS, Bibb WF, Rice DH, Barrett TJ, Hutwagner L, Griffin PM, and Slutsker L. 1998. An outbreak of Escherichia coli O157:H7 infections associated with leaf lettuce consumption. J. Infect. Dis. 177: 1588-1593.

Adams MR, Moss MO. 2000. Food microbiology. 2nd ed. Cambridge: Royal Society of Chemistry.

AkibaM, Sameshima T, and Nakazawa M. 2000. Clonal turnover of enterohemorrhagic Escherichia coli O157:H7 in experimentally infected cattle. FEMS Microbiol. Lett. 184:79-83.

Alsheekh, D A.1999. Isolation and identification of lactobacillus acidophilus and studying of some its properties and using it in production of therapeutical dairy products. Ph.D. thesis. University of Baghdad.

Ammon A, Petersen LR, and Karch H. 1999. A large outbreak of hemolytic uremic syndrome caused by an unusual sorbitol-fermenting strain of
Escherichia coli O157:H7. J. Infect. Dis. 179:1274-1277.

Ashenafi, M, 1999. Growth of Listeria monocytogenes in fermenting tempeh made of various beans and its inhibition by Lactobacillus plantarum. Food Microbiol., 8: 303-310.

Auclair J, Accolas JP (1983). Use of thermophilic lactic starters in the dairy industry. Antonie Van Leeuwenhoek, 49: 313-326.

Barnes JH, Vaillancourt JP, Gross WB, 2003. (eds.): disease of Poultry, 11th edn. Lowa state university press; Ames, lowa, USA. pp. 631-652.

Bender JB, C.W. Hedberg, J.M. Besser, D.J. Boxrud, K.L. MacDonald, and M. T. Osterholm. 1997. Surveillance by molecular subtype for Escherichia coli O157:H7 infections in Minnesota by molecular subtyping. N. Engl. J. Med. 337: 388-394.

Bibiloni R, Fedorak RN, Tannock GW, Madsen KL, Gionchetti P, Campieri M, De Simone C, Sartor RB (2005). Probiotic-mixture

Biller JA, Katz AJ, Floves AF, Buie TM, and Gorbach SL. 1995. Treatment of recurrent Clostridium difficile colitis with Lactobacillus GG. Journal of Pediatric Gastroenterology and Nutrition, 21, 224-226.

Bin-Nun A, Bromiker R, Wilschanski M, Kaplan M, Rudensky B, Caplan M, Hammerman C. 2005. Oral probiotics prevent necrotizing enterocolitis in very low birth weight neonates. Pediatrics, 147: 192- 196.

Chakraborty SP, KarMahapatra S, Roy S. Biochemical characters and antibiotic susceptibility of Staphylococcus aureus isolates. Asian Pacific Journal of Tropical Biomedicine. 2011; 1(3): 192-196.

Chakraborty SP, KarMahapatra S, Bal M, Somenath Roy. Isolation and Identification of Vancomycin Resistant Staphylococcus aureus from Post Operative Pus Sample. J. Med Sci. 2011:4: 152168.

Chalmers, R.M., Aird, H. and Bolton, F.J. 2000. Waterborne Escherichia coli O157. Journal of Applied Microbiology 88 (Suppl.), 124S-132S.

Cheesbrough, M., 1991. Medical laboratory manual for tropical countries (ELBS edn.), Vol. 2, Microbiology. Tropical Health Technology and Butterworth-Heinemann, Graet Britain.

Dontorou C, Papadopoulou C, Filioussis G, 2003. Isolation of Escherichia coli O157:H7 from foods in Greece. Int J Food Microbiol; 82: 2739. 
Drago, L.M.R., A. Gismondo, C. Lombardi and L. Gozzin, 1997. Inhibition of in vitro growth of enteropathogens by new Lactobacillus isolates of human intestinal origin. Lett. Applied Microbiol., 153: 455-463.

Friedman, M. S., T. Roels, J. E. Koehler, L. Feldman, W. F. Bibb, and P. Blake. 1999. Escherichia coli O157:H7 outbreak associated with an improperly chlorinated swimming pool. Clin. Infect. Dis. 29:298-303.

Ghadir S, El-Housseiny, Mohammad M, Aboulwafa, Nadia A, Hassouna 2010. Cytotoxic Activities of Some Escherichia coli Isolates: Possible Mechanisms and Approaches for Inhibition. Journal of American Science.,6(10):260-268.

Griffin P M (1995) Infections of the Gastrointestinal Tract, edsBlaser M J, Smith P D, Ravdin J I, Greenberg H B, Guerrant R L (Raven, New York), pp 739-761.

Hameed, A. H.(2004): Using of metabolic products of lactic acid bacteria in preservation of cheese and cream. Ph.D. Thesis. University of Baghdad.

Hemashenpagam N. and Saranya. S, 2011, Antagonistic activity and antibiotic sensitivity of Lactic acid bacteria from fermented dairy products $A d v$. Appl. Sci. Res., 2 (4):528-534

Hirano, J., T. Yoshida, T. Sugiyama, N. Koide, I. Mori and T. Yokochi, 2003. The Effect of Lactobacillus rhamnosus on enterohemorrhagic Escherichia coli infection of human intestinal cells in vitro. Microbiol. Immunol., 47: 405-409.

Hassan Pyar, K.K. Peh and Min-TzeLiong, 2011. Inhibitory Effect of Metabolites from Probiotics Lactobacillus acidophilus Strains on Growth of Pathogenic Bacteria. Journal of Pharmacology and Toxicology, 6: 533-540.

Hols P, Hancy F, Fontaine L, Grossiord B, Prozzi D, Leblond-Bourget $\mathrm{N}$, Decaris $\mathrm{B}$, Bolotin $\mathrm{A}$, Delorme C, Dusko Ehrlich S, Guedon E, Monnet V, Renault P, Kleerebezem M (2005). New insights in the molecular biology and physiology of $S$. thermophilus revealed by comparative genomics. FEMS Microbiol., 29: 435-463.

Holzapfel, W.H., P. Haberer, R. Geisen, J. Bjorkroth and U. Schillinger, 2001. Taxonomy and important features of probiotic microorganisms in food and nutrition. Am. J. Clin. Nutr., 73: 365S-373S.

Jacobsen CN (1999). Screening of probiotic activities of forty-seven strain Lactobacillus ssp. by in vitro techniques and evaluation of the colonization ability of five selected strains in Umans. Appl. Environ. Microbial., 65: 4949-4956.
Kanungo S. 2009 A Simplified Analysis of Different Escherichia coli Strains by Using RAPD Technique. Not. Bot. Hort. Agrobot. Cluj., 37: 257-260.

Lavermicocca, P., F. Valerio, A. Evidente, S. Lazzaroni, A. Corsetti and M. Gobetti, 2000. Purification and characterization of novel antifungal compounds from the sourdough Lactobacillus plantarum strain 21B. Applied Environ. Microbiol., 66: 4084-4090.

Lee, S.H., Levy, D.A., Craun, G.F., Beach, M.J. and Calderon, R.L. (2002) Surveillance for Waterborne-disease outbreaks - United States, 1999-2000. Morbidity and Mortality Weekly Report Surveill. Summ. 51, 1-47.

MacFaddin JF. Biochemical Tests for Identification of Medical Bacteria. 3rd ed. Philadelphia; 2000. Lippincott Williams and Wilkins, pp 451-453.

McCarthy, T.A., Barrett, N.L., Hadler, J.L., Salsbury, B., Howard, R.T., Dingman, D.W., Brinkman, C.D., Bibb, W.F. et al., (2001) Hemolytic-uremic syndrome and Escherichia coli O121 at a lake in Connecticut, Pediatrics 108, E59.

NCCLS. Methods for Dilution Antimicrobial Susceptibility Tests for Bacteria that Grow Aerobically, 5th edn, 17, no. 2. Approved standard M7-A5; 2006. Wayne, PA: NCCLS.

Okeke IN, Fayinka ST, Lamikanra A. Antibiotic Resistance in Escherichia coli from Nigerian Students, 1986-1998. Emerging Infectious Diseases. 2000; 6: 393-396.

Saavedra, J.M., Bauman, N.A., Oung, I., Perman, J.A., and Yolken, R.H. (1994). Feeding of Bifidiobacterium bifidum and Streptococcus thermophilus to infants in hospital for the prevention of diarrhea and shedding of rotavirus. Lancet, 344, 1046-1049.

Sakagami, Y., H. Murata, T. Nakanishi, Y. Inatomi and K. Watabe et al., 2001. Inhibitory effect of plant extracts on production of verotoxin by enterohemorrhagic Escherichia coli O157: H7. J. Health Sci., 47: 473-477.

SchillingerU, and Lucke F.1989 Antimicrobial activity of Lactobacillus sake isolated from meat. J Appl Environ Microbiol., 55: 1901-1906.

Shah NP (2007). Functional cultures and health benefits. Int. Dairy J., 17: 1262-1277.

Shamir R, Makhoul IR, Etzioni A, Shehadeh N (2005). Evaluation of diet containing probiotics and zinc for the treatment of mild diarrheal illness in children younger than one year of age. J. Am. Colle. Nutr., 24: 370-375. 
Strockbine N A, Wells J G, Bopp C A, Barrett T J (1998) Escherichia coli O157:H7 and Other Shiga Toxin-Producing E. coli Strains, eds. Kaper J B, O'Brien A D (Am. Soc. Microbiol. Washington, DC), pp 331-356

Suskovic, J., Brkic, B., Matosic, S. and Maric, V. (1997): lactobacillus acidophilus M92 as potential probiotic strain. Milchwissenschaft, 52(8): 430435.

World Health Organization (1998) Zoonotic non-O157 Shiga toxin-producing Escherichia coli (STEC). Report of a WHO Scientific Working Group Meeting [online: http://www.who.int/emcdocuments/zoonoses/whocsraph988c.html

\section{How to cite this article:}

Zainab M. AlZubaidy. 2019. Determination of Antibacterial Activity of Cell Free Extracts of Lactobacillus bulgaricus and Streptococcus thermophilus against Local Isolates of E. coli O157:H7. Int.J.Curr.Res.Aca.Rev. 7(3), 22-31. doi: https://doi.org/10.20546/ijcrar.2019.703.003
Zinnah MA, Bari MR, Islam MT, Hossain MT, Rahman MT, Haque MH, Babu SAM, Ruma RP Islam MA. Characterization of Escherichia coli isolated from samples of different biological and environmental sources. Bangl J Vet Med. 2007; 5: $25-32$.

Zarringhalam, M., Moghaddam, M. Sattari, A.M. Mobarez and F. Doctorzadeh, 2006. Inhibitory effect of yogurt Lactobacilli bacteriocins on growth and verotoxins production of enterohemorrhagic Escherichia coli O157:H7. Pakistan Journal of Biological Sciences, 9: 2112-2116. 